\title{
Biologically Active Constituents from Salix viminalis Bio-Oil and Their Protective Activity Against Hydrogen Peroxide-Induced Oxidative Stress in Chinese Hamster Ovary Cells
}

\author{
Anna Ilnicka • Katarzyna Roszek • Andrzej Olejniczak • \\ Michal Komoszynski • Jerzy P. Lukaszewicz
}

Received: 17 May 2014 / Accepted: 15 August 2014 /

Published online: 30 August 2014

(C) The Author(s) 2014. This article is published with open access at Springerlink.com

\begin{abstract}
The protective antioxidative effect of the phenolic extract (PE) isolated from Salix viminalis pyrolysis derived bio-oil was shown in vitro on the Chinese hamster ovary (CHO) cells exposed to hydrogen peroxide $\left(\mathrm{H}_{2} \mathrm{O}_{2}\right)$. Cells pretreated with $0.05 \mu \mathrm{g} / \mathrm{ml} \mathrm{PE}$ after exposure to different concentrations of $\mathrm{H}_{2} \mathrm{O}_{2}(300-900 \mu \mathrm{M})$ showed up to $25 \%$ higher viability than the unpretreated ones. The antioxidative effect of PE was also observed in a time-dependent manner. The results were confirmed by visual examination of the specimens using microscopy. Finally, superoxide dismutase (SOD) activity modulation was shown by SOD assay, designed to determine the activity of enzymes removing free radicals.
\end{abstract}

Keywords Salix viminalis $\cdot$ Pyrolysis $\cdot$ Bio-oil $\cdot$ Phenolic extract $\cdot$ Antioxidants $\cdot$ Oxidative stress

\section{Introduction}

Pyrolysis of biomass is listed among the most promising technologies able to overcome the global challenges arising from a shortage of fossil fuels, increasing demands for energy, and environmental concerns as well. Bio-oil, being the main product of the biomass pyrolysis, has the potential to be used for producing fuels and value-added chemicals.

It is known that bio-oils contain a huge variety of phenolic species resulting from breakdown of lignin, which are responsible for their antioxidant properties. Basically, they can be

\footnotetext{
A. Ilnicka $\cdot$ A. Olejniczak $\cdot$ J. P. Lukaszewicz $(\bowtie)$

Faculty of Chemistry, Nicolaus Copernicus University, ul. Gagarina 7, 87-100 Torun, Poland e-mail: jerzy_lukaszewicz@o2.pl

K. Roszek $\cdot$ M. Komoszynski

Faculty of Biology and Environment Protection, Nicolaus Copernicus University, ul. Gagarina 7, 87-100 Torun, Poland
}

A. Olejniczak

Flerov Laboratory of Nuclear Reactions, Joint Institute for Nuclear Research, Joliot-Curie 6, Dubna, Russia 141980 
classified as water-insoluble, high-molecular weight components (pyrolytic lignin) and watersoluble, low molecular weight ones (mainly monomers). The antioxidant properties of whole bio-oils and their fractions consisting of low- and high molecular weight components were proved using various chemical assays [1]. Significant effort has been made for the antioxidant characterization of pyroligneous acids (also known as liquid smoke) obtained by condensation of smoke generated during wood carbonization [2-4]. These liquids have a composition closely similar to that of bio-oils, except for the absence of low-volatile components, like pyrolytic lignin and sugars. Their antioxidant capacity was determined by several methods, including activities against of ABTS radical cation [4], hydroxyl radical $(\mathrm{OH})$ [5], superoxide radical anion $\left(\mathrm{O}_{2}^{-}\right)$[5], and DPPH radical [3-5] as well as phosphomolibdenium [3, 4] and FRAP [3-5] reducing assays. The antioxidant capacity of pyrolysis liquids was demonstrated to be lower than pyrolytic lignin $[1,6]$, however, still comparable or even superior to that of many synthetic antioxidants, including BHA, BHT, and $\alpha$-tocopherol $[3,7]$.

The biological activity has been studied for some of the individual bio-oil components only. Among these studies, one should mention the evaluation of antioxidant, anti-inflammatory, and hepatoprotective properties of vanillin in carbon tetrachloride-treated rats [8], suppression of oxidative stress, and carcinogenesis in Helicobacter pylori by 4-vinyl-2,6-dimethoxyphenol treatment [9].

A very limited number of studies have been devoted to investigating the interaction of biooils and other wood pyrolysis liquids with biological systems in vivo and in vitro [10, 11]. According to Pimenta et al. [12], eucalyptus-derived pyrolysis liquid and its phenolic fraction are characterized by moderate toxicity, being able to immobilize $50 \%$ of the Daphnia magna population after 24-h exposure at concentrations of 170 and $68 \mathrm{mg} / \mathrm{l}$, respectively. No genotoxic effect of the pyrolysis liquid was found, as evaluated by Microtox assay applied with and without exogenous metabolic activation. Similarly, no genotoxic effect of phenolic fraction (lower phase) obtained by fast pyrolysis of Radiata Pine was found, as assessed by Park et al. [13] using the comet assay. The authors observed that the cytotoxicity of the phenolic fraction is much lower than its acute toxicity on D. magna and linked this observation to the particular sensitivity of crustacea to methoxy phenols. The upper (nonphenolic) fraction of bio-oil was suggested to contain the compounds of higher cyto- and genotoxicity, but less toxic towards D. magna. Chatterjee et al. [14] studied the activity of whole bio-oils produced by slow pyrolysis of rice straw and sawdust. They demonstrated that cytotoxicity, apoptosis, and genotoxicity in Jurkat $\mathrm{T}$ (human lymphoma) and HepG2 cell cultures increases with the bio-oil dose. Similarly, a dose-dependent relation was observed for in vivo survivability of Caenorhabditis elegans. Recently, a beneficial effect of hickory shell-derived pyroligneous acid was demonstrated on C. elegans exposed to oxidative stress in vivo [15]. Hong et al. [16] studied pyrolyzates derived from low-temperature heat treatment $\left(150-200{ }^{\circ} \mathrm{C}\right)$ of bamboo. Treatment with high concentrations of pyrolyzates leads to the decreased cell viability, whereas cells treated with low concentrations showed higher viability than control. The protective effect of the pyrolyzates against $N$-methyl-D-aspartate (NMDA)-induced apoptotic cell damage in cortical neurons was demonstrated as well.

In our previous studies, we demonstrated the successful isolation of phenolic constituents from $S$. viminalis pyrolysis bio-oil. Chromatographic analysis revealed that the high ratio of syringylpropane units to guaiacylpropane units characteristic of the lignin of $S$. viminalis leads to high levels of syringol and its para-substituted derivatives in the bio-oil. The results of quantitative gas chromatographic analysis of the phenolic extract are presented in [17]. The ingredients work is known to exhibit high antioxidative efficiency resulting from the electronic effects of ortho-methoxy and para-substituents. So far, we examined phenolic components of $S$. viminalis-derived pyrolysis oil with regard to their potential application to the oxidative 
stabilization of synthetic lubricating oils. In these studies, two phenolic fractions were isolated through solvent extraction (extract A was ether soluble; extract B was methylene chloride soluble) and characterized by chromatographic analysis. Both extracts showed bang up the antioxidative effect of the obtained extracts on PAOs and diesters, high-temperature oxidation tests. Nevertheless, there are no reports in the literature concerning the bio-oil from $S$. viminalis and its antioxidant activity against oxidative stress-treated cells in vivo which prompted us to undertake this type of research.

A variety of pathological states have been associated with oxidative damage or stress that is mediated by excessive exposure of cells to reactive oxygen species such as free radicals [18]. Hydrogen peroxide can be the source of one of the most reactive free radicals-hydroxyl radical. Prime targets for free radical reactions are the unsaturated bonds in membrane lipids. Consequent peroxidation results in a loss in membrane fluidity and potentially in cellular lysis. Other effects of free radical damage include DNA mutations and inactivation of disulfide bounds containing enzymes [19-22].

\section{Materials and Methods}

\section{Separation of Phenolic Antioxidants from Bio-Oil}

Bio-oil was obtained in the process of thermal treatment of $S$. viminalis wood, according to the procedure described in [17]. The fractions of phenolic antioxidants were isolated from the resulting bio-oil by a two-step solvent extraction procedure using the Scholze and Meier method [23]. Briefly, the designated amount of bio-oil was added dropwise and under vigorous stirring into chilled deionized water. Next, the water-insoluble pyrolytic lignin fraction was removed by vacuum filtration. The water-soluble phase was extracted with diethyl ether and then with methylene chloride. Finally, the organic solvents from the resulting fractions were removed in a rotary evaporator under the reduced pressure. As it was demonstrated earlier, the ether-soluble fraction contained higher concentration of phenolic antioxidants and performed significantly better in the high-temperature oxidation tests. Thus, in the present study, only this fraction labeled as $\mathrm{PE}$ was assayed for protective action against $\mathrm{H}_{2} \mathrm{O}_{2}$-induced oxidative stress in vitro. Detailed composition of the low-molecular-weight components of the ether-soluble fraction is reported in [17].

\section{Cell Cultures}

CHO cell line was obtained from Sigma-Aldrich. The cells were grown in Ham's F-12 medium containing $10 \% \mathrm{FBS}, 100 \mathrm{U} / \mathrm{ml}$ of penicillin, and $100 \mu \mathrm{g} / \mathrm{ml}$ of streptomycin in a humidified atmosphere of $5 \% \mathrm{CO}_{2}$ at $37{ }^{\circ} \mathrm{C}$ for $24 \mathrm{~h}$ prior to the experiment.

\section{Assessment of the Cytotoxicity of PE Towards CHO Cells}

The ether extract showed a higher antioxidant activity. Therefore, the same extract was used in the next stage of the study on the biological activity. The viability of the cells was assessed by the MTT assay. The yellow MTT [3-(4,5-dimethylthiazol-2-yl)-2,5-diphenyltetrazolium bromide] is reduced to a purple formazan by mitochondrial enzymes. To determine the highest concentration of PE which does not induce any apparent cytotoxicity, the CHO cells were incubated for $24 \mathrm{~h}$ with different concentrations of PE. The cytotoxicity was basically assessed the MTT assay according to $[24,25]$ after preliminary examination by Trypan blue exclusion 
test [26]. Based on these preliminary tests, the PE concentration of $0.05 \mu \mathrm{g} / \mathrm{ml}$ was chosen for antioxidative assays in vitro.

\section{Protective Effect of PE Against $\mathrm{H}_{2} \mathrm{O}_{2}$-Induced Oxidative Stress in Vitro}

$\mathrm{CHO}$ cells were subjected to two different treatment regimens involving $\mathrm{H}_{2} \mathrm{O}_{2}$ as oxidative stress inducing agent. In the first experiment, both the unpretreated cells and the cells pretreated for $24 \mathrm{~h}$ with $0.05 \mu \mathrm{g} / \mathrm{ml}$ PE were exposed to different concentrations of $\mathrm{H}_{2} \mathrm{O}_{2}$ $(300$ to $900 \mu \mathrm{M}$ ) for the next $24 \mathrm{~h}$. Second experiment was carried on analogously, except that the cells were exposed to $\mathrm{H}_{2} \mathrm{O}_{2}$ at the highest concentration of $900 \mu \mathrm{M}$ and the treatment time was 12,24 , or $48 \mathrm{~h}$. The viability of $\mathrm{CHO}$ cells in both experiments was determined by the MTT assay and expressed as the percent ratio of the control sample.

SOD Activity

SOD activity was determined by the method of Beauchamp and Fridovich based on the inhibition of the nitroblue tetrazolium (NBT) reduction reaction [27]. The product of NTB reduction was detected spectrophotometrically at $560 \mathrm{~nm}$. The final SOD activity was expressed in SOD units per milligram of the protein in the sample, where SOD units express the amount of the SOD enzyme required to inhibit the reduction of NBT by $50 \%$.

\section{Determination of Protein Content—Bradford Assay}

The Bradford assay is a protein determination method that involves the binding of Coomassie Brilliant Blue G-250 dye to proteins [28]. The dye exists in three forms: cationic (red), neutral (green), and anionic (blue). Under acidic conditions, the dye is predominantly in the doubly protonated red cationic form (Abs $\max =470 \mathrm{~nm}$ ). However, when the dye binds to protein, it is converted to a stable unprotonated blue form $(\mathrm{Abs} \max =595 \mathrm{~nm})$. It is this blue protein-dye form that is detected at $595 \mathrm{~nm}$ in the assay using a spectrophotometer.

The CHO cells were lysed using cell lysis buffer (Cell Signaling Technology), containing $1 \%$ Triton X-100 and $1 \mathrm{mM}$ PMSF (proteases inhibitor), according to the manufacturer's protocol. The cell lysate diluted in Tris $-\mathrm{HCl}$ buffer, $\mathrm{pH}=7.6$ was mixed with a Bradford reagent. After $5 \mathrm{~min}$, the absorbance at $595 \mathrm{~mm}$ was recorded.

\section{Results and Discussion}

To determine the range of effective concentrations of hydrogen peroxide, capable to induce oxidative stress, $\mathrm{CHO}$ cells cultured for $24 \mathrm{~h}$ without addition of PE were treated for the next $24 \mathrm{~h}$ with increasing concentrations of $\mathrm{H}_{2} \mathrm{O}_{2}$. The viability results are summarized in Table 1 .

$\mathrm{H}_{2} \mathrm{O}_{2}$ in the concentrations ranging from 300 to $900 \mu \mathrm{M}$ decreased the proliferation and viability of $\mathrm{CHO}$ cells to 54,43 , and $40 \%$ of the control, respectively. On the other hand, the decrease in viability of cells pretreated with PE was lower by 25-11\%, depending on the $\mathrm{H}_{2} \mathrm{O}_{2}$ concentration.

On the microscopic observations, the morphological changes triggered probably by intracellular ultrastructural damages were visible by the treatment with 300 to $900 \mu \mathrm{M} \mathrm{H}_{2} \mathrm{O}_{2}$ (Fig. 1c, e, g). We found that pretreatment with $0.05 \mu \mathrm{g} / \mathrm{ml}$ phenolic extract not only increases the viability of $\mathrm{CHO}$ cells exposed to various concentrations of hydrogen peroxide, but also maintains unchanged morphology (Fig. 1d, f, h). The antioxidative effect of pretreatment with 
Table 1 The viability of CHO cells treated with increasing concentrations of hydrogen peroxide

\begin{tabular}{lll}
\hline Sample & & Viability (\%) \\
\hline Cells without pretreatment & Control $^{\mathrm{a}}$ & 100 \\
& $300 \mu \mathrm{M} \mathrm{H}_{2} \mathrm{O}_{2}$ & 54 \\
& $600 \mu \mathrm{M} \mathrm{H}_{2} \mathrm{O}_{2}$ & 43 \\
Cells pretreated with $0.05 \mu \mathrm{g} / \mathrm{ml} \mathrm{PE}$ for $24 \mathrm{~h}$ & $900 \mu \mathrm{M} \mathrm{H}_{2} \mathrm{O}_{2}$ & 40 \\
& $\mathrm{Control}^{\mathrm{a}}$ & 790 \\
& $300 \mu \mathrm{M} \mathrm{H}_{2} \mathrm{O}_{2}$ & 65 \\
& $600 \mu \mathrm{M} \mathrm{H}_{2} \mathrm{O}_{2}$ & 51 \\
\hline
\end{tabular}

The viability of cells was determined by the MTT assay

${ }^{\mathrm{a}}$ The control sample - $\mathrm{CHO}$ cells cultured in standard conditions without hydrogen peroxide addition

$0.05 \mu \mathrm{g} / \mathrm{ml}$ phenolic extract was also observed with $\mathrm{CHO}$ cells exposed to $900 \mu \mathrm{M} \mathrm{H} \mathrm{H}_{2} \mathrm{O}_{2}$ in time-dependent manner (Table 2; Fig. 2). After $48 \mathrm{~h}$ of culture in the presence of $900 \mu \mathrm{M}$ $\mathrm{H}_{2} \mathrm{O}_{2}$, less than $1 \%$ of $\mathrm{CHO}$ cells remained alive. Whereas cells pretreated with PE showed lower reduction in their viability and after 48-h treatment, still $24 \%$ of cells remained alive.

We have also determined the activity of superoxide dismutase as one of the possible mechanisms of cell defense against free radicals. The SOD activity was raised in the cells pretreated with the phenolic extract (Table 3).

The process of slow pyrolysis of $S$. viminalis wood results in generation of charcoal, bio-oil, and biogas [29]. The phenolic fractions extracted from the bio-oil of $S$. viminalis contain a range of compounds with antioxidative properties. Proven antioxidant activity of $S$. viminalis bio-oil-derived PEs, especially reinforced in hydrogen-bond-accepting (HBA) solvents, suggests their potential applicability for the antioxidant protection.

To test its protective biological activity, we added various concentrations of $\mathrm{PE}$ to $\mathrm{CHO}$ cell line cultured in standard conditions. In preliminary experiments, we determined the maximum dose of PE that was nontoxic to the $\mathrm{CHO}$ cells (data not shown). We have found that virtually no difference was seen in cell number and viability between controls and cells treated with $0.05 \mu \mathrm{g} / \mathrm{ml}$ PE.

We have tested the viability of $\mathrm{CHO}$ cells pretreated for $24 \mathrm{~h}$ with $0.05 \mu \mathrm{g} / \mathrm{ml}$ extract and exposed for various concentrations of hydrogen peroxide for the next $24 \mathrm{~h}$. Our results indicate that exposure of $\mathrm{CHO}$ cells to various concentrations of $\mathrm{H}_{2} \mathrm{O}_{2}$ resulted in decreasing of cells viability expressed by activity towards MTT. We have also observed that $\mathrm{CHO}$ cells exposed to high doses of $\mathrm{H}_{2} \mathrm{O}_{2}$ changed their morphology - the cells were smaller and shrunken in comparison with unaffected cells. This was probably caused by oxidative damage of cell membrane and changes in its permeability. After exposure to $\mathrm{H}_{2} \mathrm{O}_{2}$, cells pretreated with $0.05 \mu \mathrm{g} / \mathrm{ml}$ PE not only showed 11 to $25 \%$ higher viability than the unpretreated ones, but also maintained unchanged morphology. The antioxidative effect of pretreatment with $0.05 \mu \mathrm{g} / \mathrm{ml}$ phenolic extract for $24 \mathrm{~h}$ was also observed with $\mathrm{CHO}$ cells exposed to $900 \mu \mathrm{M}$ hydrogen peroxide in time-dependent manner. In this case, the exposition time of $48 \mathrm{~h}$ was long enough to induce cell death in all $\mathrm{CHO}$ cells, whereas PE pretreated cells still showed the viability of $24 \%$.

It has to be stated that the phenolic extract was used without any extensive purification and as such may contain compounds of proven cytotoxic activity, e.g., phenol, catechol, etc. Phenol induces diverse effects on the epithelial barrier function in vitro. These cellular 

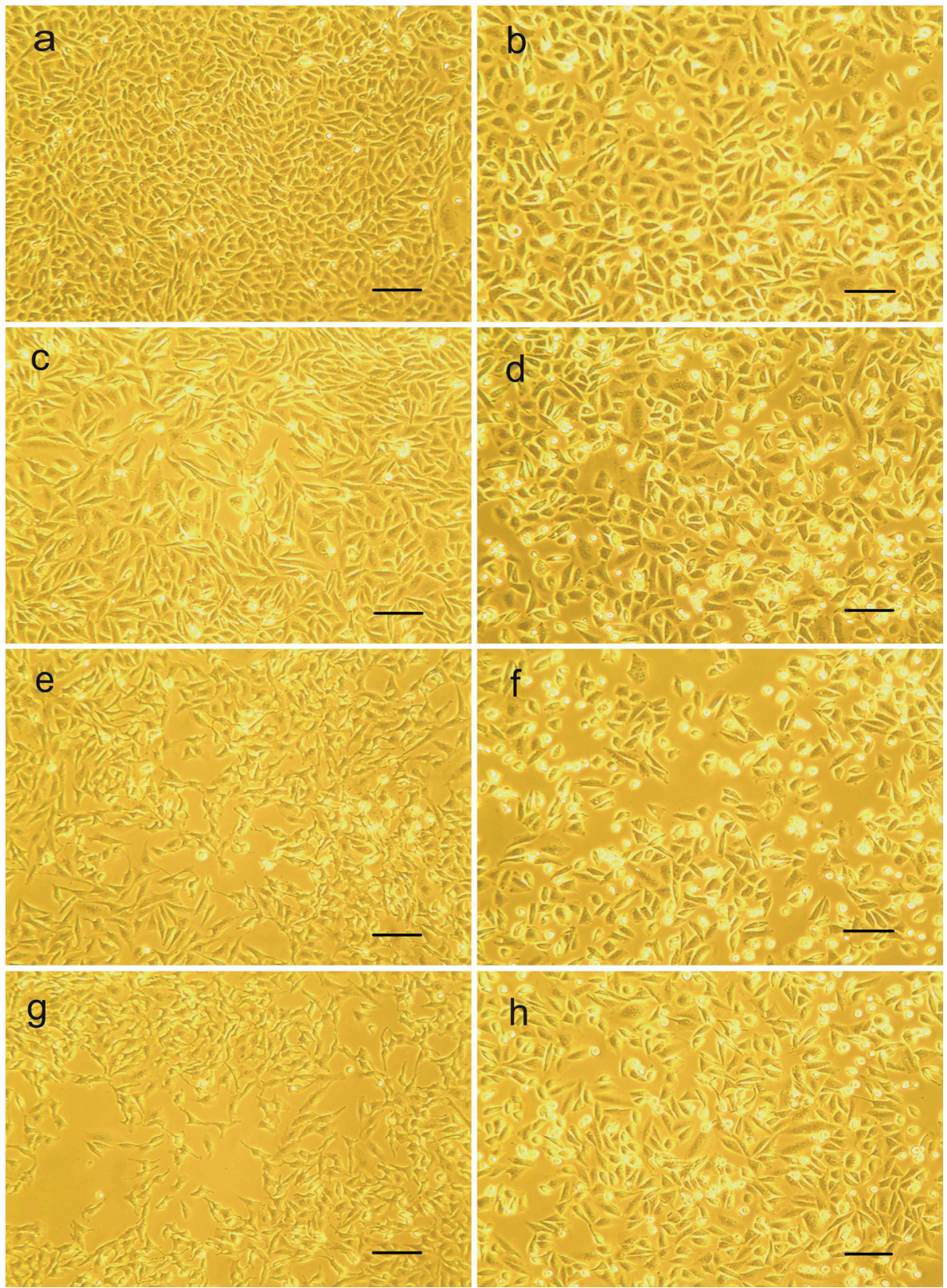

Fig. 1 Chinese hamster ovary (CHO) cells $72 \mathrm{~h}$ after passaging: cultured without any supplementation (a), pretreated with $0.05 \mu \mathrm{g} / \mathrm{ml}$ phenolic extract for $24 \mathrm{~h}$, without hydrogen peroxide addition (b), cells exposed for $24 \mathrm{~h}$ to $300 \mu \mathrm{M} \mathrm{H}_{2} \mathrm{O}_{2}$ (c), $600 \mu \mathrm{M} \mathrm{H}_{2} \mathrm{O}_{2}$ (e), and $900 \mu \mathrm{M} \mathrm{H}_{2} \mathrm{O}_{2}$ (g), cells pretreated with $0.05 \mu \mathrm{g} / \mathrm{ml}$ phenolic extract for $24 \mathrm{~h}$ and then exposed for $24 \mathrm{~h}$ to $300 \mu \mathrm{M} \mathrm{H}_{2} \mathrm{O}_{2}$ (d), $600 \mu \mathrm{M} \mathrm{H}_{2} \mathrm{O}_{2}$, (f) and $900 \mu \mathrm{M} \mathrm{H}_{2} \mathrm{O}_{2}$ (h). Scale bar $100 \mu \mathrm{m}$

membrane microdomains are affected by phenol exposure, thus destabilizing the tight junction proteins that regulate epithelial barrier function in cells, as described in [30]. Phenol also elicits 
Table 2 The viability of $\mathrm{CHO}$ cells treated with $900 \mu \mathrm{M}$ hydrogen peroxide for 12,24 , and $48 \mathrm{~h}$

\begin{tabular}{lll} 
Sample & Viability of cells without pretreatment $(\%)$ & $\begin{array}{l}\text { Viability of cells pretreated with } 0.05 \mu \mathrm{g} / \mathrm{ml} \\
\text { PE for } 24 \mathrm{~h}(\%)\end{array}$ \\
\hline Control $^{\mathrm{a}}$ & 100 & 100 \\
$12 \mathrm{~h}$ & 54 & 62 \\
$24 \mathrm{~h}$ & 36 & 42 \\
$48 \mathrm{~h}$ & $<1$ & 24 \\
\hline
\end{tabular}

The viability of cells was determined by the MTT assay

${ }^{a}$ The control sample - CHO cells cultured in standard conditions without hydrogen peroxide addition

a strong cytotoxic effect when added to PK-15 cells [31]. Oliveira et al. studied cytotoxicity of catechol [32]. Catechol induced time- and concentration-dependent cytotoxic effects. Morphological changes, such as the retraction of the cytoplasm and chromatin clumping, were seen in cells exposed to catechol for $48 \mathrm{~h}$. Thus, the obtained result should be understood in terms of trade-off between the harmful action of these compounds and protective activity due to the presence of components with high antioxidative potential. Based on the previously reported results showing that $\mathrm{PE}$ from $S$. viminalis bio-oil are composed mainly of 2,6dimethoxyphenol (syringol) and its para-substituted derivatives, the high antioxidative activity could be explained by the electronic effects of ortho-methoxy and para substituents. 2Methoxyphenol (guaiacol) and its derivatives, exhibiting low antioxidant activity, are present at much lower concentrations. Even lower is the content of potentially harmful components

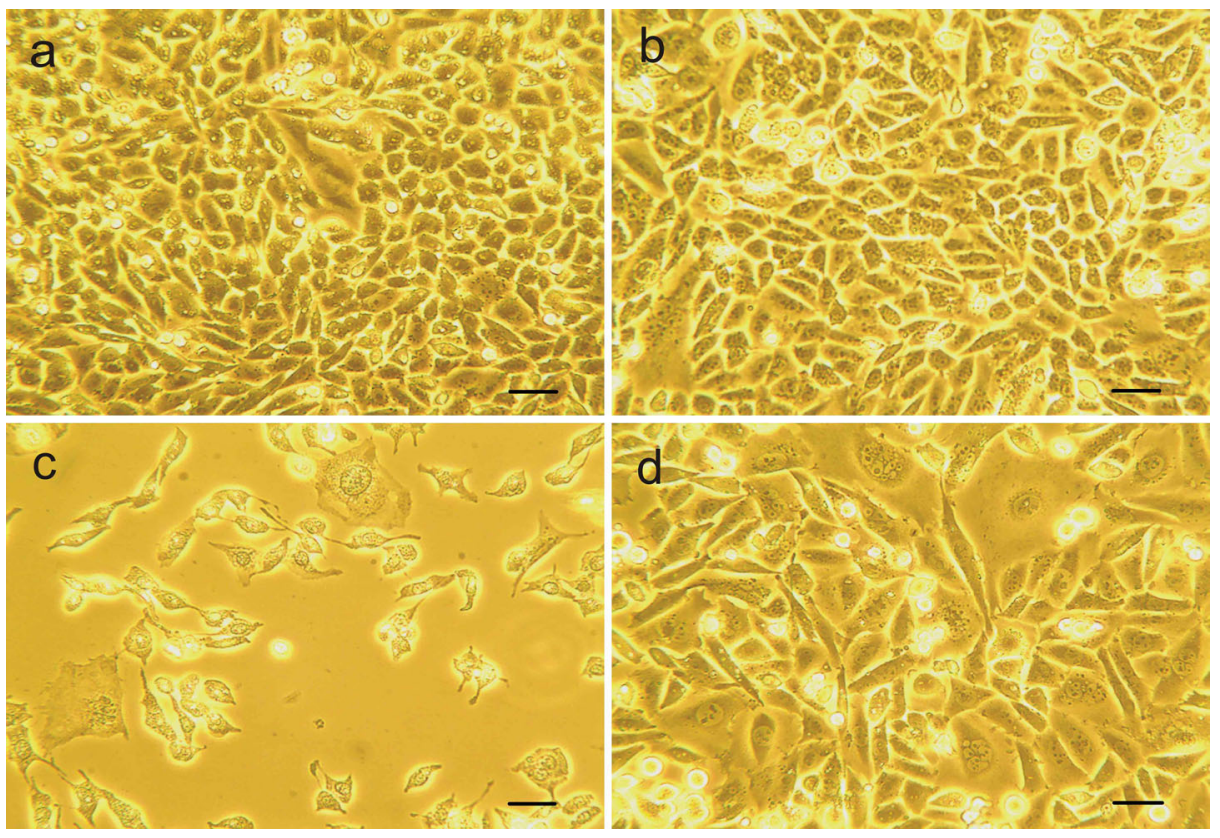

Fig. 2 Chinese hamster ovary (CHO) cells $72 \mathrm{~h}$ after passaging: cultured without any supplementation (a), pretreated with $0.05 \mu \mathrm{g} / \mathrm{ml}$ phenolic extract for $24 \mathrm{~h}$, without hydrogen peroxide addition (b), cells exposed for $48 \mathrm{~h}$ to $900 \mu \mathrm{M} \mathrm{H}_{2} \mathrm{O}_{2}$ (c), cells pretreated with $0.05 \mu \mathrm{g} / \mathrm{ml}$ phenolic extract for $24 \mathrm{~h}$ and then exposed for $48 \mathrm{~h}$ to $900 \mu \mathrm{M} \mathrm{H}_{2} \mathrm{O}_{2}$ (d). Scale bar $50 \mu \mathrm{m}$ 
Table 3 SOD activity determination of CHO cells treated with $900 \mu \mathrm{M}$ hydrogen peroxide for $24 \mathrm{~h}$

\begin{tabular}{lll}
\hline Sample & & SOD activity (U/mg protein) \\
\hline Cells without pretreatment & Control $^{\mathrm{a}}$ & 0.230 \\
& $900 \mu \mathrm{M} \mathrm{H}_{2} \mathrm{O}_{2}$ & 0.280 \\
Cells pretreated with $0.05 \mu \mathrm{g} / \mathrm{ml} \mathrm{PE}$ for $24 \mathrm{~h}$ & Control $^{\mathrm{a}}$ & 0.335 \\
& $900 \mu \mathrm{M} \mathrm{H}_{2} \mathrm{O}_{2}$ & 0.323 \\
\hline
\end{tabular}

The SOD activity of cells was determined as described in "Materials and Methods" section

${ }^{a}$ The control sample - CHO cells cultured in standard conditions without hydrogen peroxide addition

resulting from the decomposition of phenylpropane lignin units (i.e., phenol and its psubstituted derivatives). One should note that the share of the identified lowmolecular-weight components accounted only for $50 \mathrm{wt} \%$, (GC based). Our mass spectrometric studies revealed the presence of lignin dimers with molecular weight ranging from 250 to 400 amu. Some studies suggest that these are highly valuable components with lignane-like structure; however, the exact structure of lignin dimers originating from $S$. viminalis is so far unsolved.

The positive results of antioxidative tests encouraged us to undertake an attempt to recognize the possible mechanism of antioxidative activity of polyphenols from phenolic extract of $S$. viminalis. Cellular defense mechanisms against oxidative damage include enzymatic conversion of ROS to less reactive species, chelation of transition metal catalysts, and detoxification of ROS by antioxidants [33]. It is known that antioxidants may modulate the level of endogenous enzymes, such as superoxide dismutase [34]. Superoxide dismutase catalyzes the dismutation of the superoxide anion radical $\left(\mathrm{O}_{2}^{--}\right)$and as such provides an important defense mechanism against

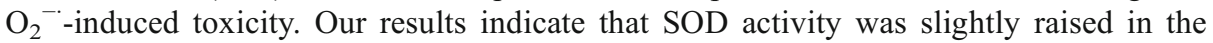
cells exposed to $900 \mu \mathrm{M} \mathrm{H}_{2} \mathrm{O}_{2}$, while the increase in the SOD activity was observed in $\mathrm{CHO}$ cells pretreated with the phenolic extract. The second observation is in agreement with recent results on antioxidant properties of vanillin in vivo, showing the ability of vanillin to increase the activity of hepatic enzyme antioxidants, including catalase and SOD [35]. This is an important factor, as the endogenous enzymes are normally easily deactivated by prolonged oxidative stress. An increased SOD activity in PE-pretreated cells compared to that of controls may indicate, however, that $\mathrm{PE}$ induces some level of oxidative stress.

\section{Conclusions}

In conclusion, our results demonstrate that $S$. viminalis bio-oil-derived phenolic extract protects cells against $\mathrm{H}_{2} \mathrm{O}_{2}$-induced oxidative stress damage. Questions on the precise mechanism of phenolic extract action and its effectiveness in various cells in vitro models remain to be answered. In the future, the new objective of our research can be assaying the biological activity of the individual compounds isolated from phenolic extract, being a complex mixture.

Open Access This article is distributed under the terms of the Creative Commons Attribution License which permits any use, distribution, and reproduction in any medium, provided the original author(s) and the source are credited. 


\section{References}

1. Dobele, G., Dizhbite, T., Urbanovich, I., Andersone, A., Ponomarenko, J., \& Telysheva, G. (2009). Journal of Analytical and Applied Pyrolysis, 85, 81-86.

2. Kjallstrand, J., \& Petersson, G. (2001). Science of the Total Environment, 277, 69-75.

3. Loo, A. Y., Jain, K., \& Darah, I. (2007). Food Chemistry, 104, 300-307.

4. Loo, A. Y., Jain, K., \& Darah, I. (2008). Food Chemistry, 107, 1151-1160.

5. Wei, Q., Ma, X., Zhao, Z., Zhang, Z., \& Liu, S. (2010). Journal of Analytical and Applied Pyrolysis, 88, 149-154.

6. Dobele, G., Dizhbite, T., Ponomarenko, J., Urbanovich, I., Kreicberga, J., \& Kampars, V. (2011). Holzforschung, 65, 503-510.

7. Rungruang P., \& Junyapoon S. (2010) Proc. 8th Int. Symp. Biocontr. Biotechnol. Biocont. Biotechnol. Pattaya (Thailand), pp. 102-106.

8. Makni, M., Chtourou, Y., Fetoui, H., Garoui, E. M., Boudawara, T., \& Zeghal, N. (2011). European Journal of Pharmacology, 668, 133-139.

9. Cao, H., Tsukamoto, T., Seki, T., Tanaka, H., Morimura, S., Cao, L., Mizoshita, T., Ban, H., Toyoda, T., Maeda, H., \& Tatematsu, M. (2008). International Journal of Cancer, 122, 1445-1454.

10. Bedmutha, R., Booker, C. J., Ferrante, L., Briens, C., Berruti, F., Yeung, K. C., Scott, I., \& Conn, K. (2011). Journal of Analytical and Applied Pyrolysis, 90, 224-231.

11. Booker, C. J., Bedmutha, R., Scott, I. M., Conn, K., Berruti, F., Briens, C., \& Yeung, K. C. (2012). International Journal of Chemical Reactor Engineering, 8, 1939. doi:10.2202/1542-6580.

12. Pimenta, A. S., Bayona, J. M., García, M. T., \& Solanas, A. M. (2000). Archives of Environment Contamination and Toxicology, 38, 169-175.

13. Park, S. Y., Kim, J. S., Park, Y. K., \& Choi, J. H. (2008). Journal of Environmental and Toxicology, 23, $187-194$.

14. Chatterjee, N., Eom, H. J., Jung, S. H., Kim, J. S., \& Choi, J. (2013). Environmental and Toxicology. doi:10. 1002/tox.21871.

15. Cai, K., Jiang, S., Ren, C., \& He, Y. (2012). Journal of the Science of Food and Agriculture, 92, $29-36$.

16. Hong, E. J., Jung, E. M., Lee, G. S., Kim, J. Y., Na, K. Y., Park, J. M., Kang, H. Y., Choi, K. C., Seong, Y. H., Choi, I. G., \& Jeung, E. B. (2010). Journal of Ethnopharmacology, 128, 594-599.

17. Olejniczak, A., Kucinska, A., Cyganiuk, A. W., \& Lukaszewicz, J. P. (2012). Industrial and Engineering Chemistry Research, 51, 5117-5123.

18. Uttara, B., Singh, A. V., Zamboni, P., \& Mahajan, R. T. (2009). Current Neuropharmacology, 7, 65-74.

19. Ohshima, H., Tatemichi, M., \& Sawa, T. (2003). Archives of Biochemistry and Biophysics, 417, 3-11.

20. Nordberg, J., \& Arnér, E. S. J. (2001). Free Radical Biology and Medicine, 31, 1287-1312.

21. Galaris, D., \& Evangelou, A. (2002). Critical Reviews in Oncology/Hematology, 42, 93-103.

22. Cabiscol, E., Tamarit, J., \& Ros, J. (2000). International Microbiology, 3, 3-8.

23. Scholze, B., \& Meier, D. (2001). Journal of Analytical and Applied Pyrolysis, 60, 41-54.

24. Edmondson, J. M., Armstrong, L. S., \& Martinez, A. O. (1988). Journal of Tissue Culture Methods, 11, 15-17.

25. Anuszewska, E. L., Gruber, B. M., \& Koziorowska, J. H. (1997). Biochemical Pharmacology, 54, $597-603$.

26. Coligan, J. E., Kruisbeck, A. M., Margulies, D. H., Shevach, E. M., \& Strober, W. (2001). Current Protection Immunology. doi:10.1002/0471142735.ima03bs21.

27. Beauchamp, D., \& Fridovich, I. (1971). Analytical Biochemistry, 44, 276-287.

28. Bradford, M. M. (1976). Analytical Biochemistry, 72, 248-254.

29. Łukaszewicz, J. P., \& Wesołowski, R. P. (2008). Micropor Mesopor Mat, 116, 723-726.

30. McCall, C., Betanzos, A., Weber, D. A., Nava, P., Miller, G. W., \& Parkos, C. A. (2009). Toxicology and Applied Pharmacology, 241, 61-70.

31. Ciuca, V., \& Dumitrache, M. (2007). Bulletin of the University of Agriculture Science and Veterinary Medicine, 64, 108-110.

32. de Oliveira, D. M., Pitanga, B. P., Grangeiro, M. S., Lima, R. M., Costa, M. F., Costa, S. L., Clarêncio, J., \& El-Bachá, R. S. (2010). Human and Experimental Toxicology, 29, 199-212.

33. Sharma, P., Jha, A. B., Dubey, R. S., \& Pessarakli, M. (2012). Journal of Botany, 2012, 1-26.

34. Giovannini, C., Filesi, C., D’Archivio, M., Scazzocchio, B., Santangelo, C., \& Masella, R. (2006). Annali dell'Istituto Superiore di Sanità, 42, 336-347.

35. Makni, M., Chtourou, J., Fetoui, H., Garoui, E. M., Boudawara, T., \& Zeghal, N. (2011). European Journal of Pharmacology, 668, 133-139. 